\title{
Postural stability, risk of falls and fear of falling in elderly with diabetic neuropathy who do therapeutic exercises
}

\author{
Estabilidade postural, risco de quedas e medo de cair em idosos com neuropatia \\ diabética que realizam exercicios terapêuticos
}

Estabilidad postural, riesgo de caidas y miedo de caer en ancianos con neuropatía diabética que realizan ejercicios terapéuticos

Hudson Azevedo Pinheiro', Karla Helena Coelho Vilaça², Gustavo de Azevedo Carvalho

\begin{abstract}
I This study aimed to analyze postural stability, the risk of falls and fear of falling in elderly with diabetic neuropathy (DNP) that perform therapeutic exercises. The authors conducted the screening of elderly patients with DNP using the instruments Neuropathy Symptom Score (NSS) and the Neuropathy Disability Score (NDS). The 50 selected patients were divided into two groups: 24 of Gl (who were performing therapeutic exercises) and 26 of G2 (the control group). To assess postural stability, risk of falls and fear of falling among groups used the pressure platform, the Berg Balance Scale (BBS) and the Falls Efficacy Scale (FES-I). There was no significant difference in the outcome of BBS scales $(p=0.16)$ and FES-I $(p=0.15)$ between the $\mathrm{G} 1$ and $\mathrm{G} 2$; by the pressure platform, we found differences between $\mathrm{G} 1$ and $\mathrm{G} 2$ in parameters path length $(\mathrm{PL})$ and stability medio-lateral $(\mathrm{ML})$, with both eyes closed (EC). Elderly people with DNP who perform therapeutic exercise have better stability and ML and PL with EC that sedentary elderly; however, there was no association with therapeutic exercise, risk of falls and fear of falling.
\end{abstract}

Keywords | Accidental Falls; Diabetic Neuropathies; Aged.

RESUMO I Este estudo objetivou analisar a estabilidade postural, o risco de quedas e o medo de cair em idosos com neuropatia diabética (NPD) que realizam exercícios terapêuticos. Realizou-se uma triagem para rastreio de idosos com NPD por meio dos instrumentos Escore de Sintomas Neuropáticos (ESN) e Escore de
Comprometimento Neuropático (ECN). Os 50 pacientes selecionados para participar do estudo foram divididos em dois grupos: 24 do G1 (os que estavam realizando exercícios terapêuticos) e 26 do G2 (o grupo controle). Para avaliar a estabilidade postural, risco de quedas e o medo de cair entre os grupos foram utilizadas a plataforma de pressão, a Escala de Equilíbrio de Berg (EEB) e a Escala de Eficácia de Quedas (FES-I). Não foram observadas diferenças significativas no resultado das escalas EEB $(p=0,16)$ e FES-I $(p=0,15)$ entre o G1 e o G2; pela plataforma de pressão, foram encontradas diferenças entre G1 e G2 nos parâmetros comprimento da trajetória (CT) e estabilidade médio-lateral (ML), ambos com os olhos fechados (OF). Os idosos com NPD que realizam exercícios terapêuticos apresentam melhor estabilidade ML e no CT com OF que idosos sedentários; contudo, não foram observadas associações com o exercício terapêutico, risco de quedas e medo de cair.

Descritores | Acidentes por Quedas; Neuropatias Diabéticas; Idoso.

RESUMEN I Este estudio tuvo como objetivo analizar la estabilidad postural, el riesgo de caídas y el miedo de caer en mayores con neuropatía diabética (NPD) que realizan ejercicios terapéuticos. Se realizó un cribado para la detección de mayores con NPD por medio de los instrumentos Escala de Síntomas Neuropaticos (ESN) y Escala de

Study conducted in the Ambulatório de Geriatria da Unidade Mista de Taguatinga (UMT) - Brasília (DF), Brazil. 'Secretaria Estadual de Saúde do Distrito Federal (SES/DF); Physical Therapy of the Centro Universitário EuroAmericano de Brasilia (UNIEURO) - Brasilia (DF), Brazil.

${ }^{2}$ Graduate Program in Gerontology of the Universidade Católica de Brasília (UCB) - Brasília (DF), Brazil. 
Discapacidad Neuropática (EDN). Los 50 pacientes seleccionados para participar del estudio fueron divididos en dos grupos: 24 del G1 (los que estaban realizando ejercicios terapéuticos) y 26 del G2 (el grupo control). Para evaluar la estabilidad postural, riesgo de caídas y el miedo de caer entre los grupos fueron realizadas la plataforma de presión, la Escala de Equilibrio de Berg (EEB) y la Escala de Eficacia de Caedas (FES-I). No se observaron diferencias significativas en los resultados de las escalas de EEB $(p=0,16)$ y FES-I $(p=0,15)$ entre el G1 y el G2; por la plataforma de presión, se encontraron diferencias entre G1 y G2 en los parámetros longitud de la trayectoria (LT) y estabilidad mediolateral (ML), ambos con los ojos cerrados (OC). Los mayores con NPD que realizan ejercicios terapéuticos presentan mejor estabilidad ML y en la LT con OC que los mayores sedentarios; sin embargo, no se observaron asociaciones con el ejercicio terapéutico, riesgo de caídas y el miedo de caer.

Palabras clave I Accidentes por Caídas; Neuropatías Diabéticas; Anciano.

\section{INTRODUCTION}

Diabetes mellitus (DM) is a public health problem, with an worldwide overall prevalence expected for 2025 of 300 million people, due to the increasing aging population, in addition to the changes in lifestyle which generate risk factors for this disease, such as stress, sedentary lifestyle and obesity. Brazil is the sixth country in the world in number of people with DM, with approximately 11.3 million reported cases ${ }^{1-3}$.

The DM exerts several deleterious effects. One of them is the development of diabetic neuropathy (DNP), a condition which attacks the peripheral nervous system (PNS), usually with symmetrical and distal involvement, which leads to plantar insensitivity, muscle weakness (especially of the intrinsic muscles of the feet) and decreased range of motion ( $\mathrm{ROM})$, contributing to decreasing the inputs from the proprioceptive system, postural instability and the risk of falls ${ }^{4-6}$.

The occurrence of falls among elderly is one of the main factors of morbidity and mortality in this population, because it entails loss of mobility, social constraint, dependence on the performance of daily activities (DA) and loss of autonomy, especially among diabetics who do not have adequate glycemic control ${ }^{7-10}$.

A previous study by Bretan et al. showed a positive correlation between changes of plantar skin sensitivity and balance disorders in Brazilian elderly with DM. The authors also observed that the loss of plantar skin sensitivity is associated with risk of falls ${ }^{11}$.

Preliminary studies showed that physical therapy in individuals with DNP is effective in alleviating some symptoms, such as numbness, tingling and burning, as well as contributes to mobility and to the prevention of muscle function limitations, improvement in postural stability and muscle strength ${ }^{12-14}$. Morrison et al. observed that the functional decline in elderly diabetic with a history of falls is associated with DNP, which leads to the reduction of reactions of protection and the fear of falling. These authors also demonstrated that the muscular strength training may lead to positive effects on those individuals ${ }^{15}$.

Although there are data in the literature addressing this issue, there are still few studies which have investigated postural stability through pressure platform in elderly patients with DNP, and there are few studies which observed the physical performance among patients who were under physical therapy.

Thus, the aim of this study was to analyze postural stability, the risk of falls and the fear of falling among elderly people with DNP who practiced therapeutic exercises.

\section{METHODOLOGY}

The study was approved by the Research Ethics Committee of UCB under Protocol No. 46/2010. All volunteers received detailed information about the objectives and procedures of the study and took part in the study after signing the Informed Consent Form (TLCE).

\section{Sample}

A cross-sectional study was conducted with a convenience sample. All medical records of patients seen at two public health services in the geriatric sector of the Federal District between January and June 2011, a total of 250 patients, were analyzed. There were selected for screening those who were aged 60 years of age or more and who had type 2 DM.

Those who had type $1 \mathrm{DM}$, severely debilitated elderly, bedridden, the ones who suffered of dementia, stroke motor sequelae, plantar ulcers, amputees and those using walking aid devices at the time of the assessment, were excluded. 


\section{Assessment procedures}

The data collection was performed at the Clinical School of Physiotherapy of UCB in a single moment, with an average duration of one hour, during the month of July 2011.

A screening was performed in order to investigate the presence of DNP through the ESN and the NDS instruments, both translated and validated for the Brazilian population by Moreira et al., having, therefore, good reliability and reproducibility for the diagnosis of DNP; once the neuropathy was not confirmed, the elderly would be excluded from the study ${ }^{16}$.

After being sorted out, the selected subjects answered questions about performing therapeutic exercises: which exercises they would perform, for how long and the associated health problems. Based on this information, two groups were formed, with Group 1 (G1) consisting of individuals who performed therapeutic exercises for, at least, three months and group 2 (G2), by individuals who were not practicing any exercises.

The therapeutic exercises, which were conducted by $\mathrm{G} 1$, were prescribed by physical therapists from units where the elderly would be taken care of, and they were based on the complaints from the patients at the time of their admission. The exercises were performed with a frequency of 3 times per week, lasting 50 minutes. The program consisted of aerobic exercises performed in stationary bicycles, resistance exercises for lower (LL) and upper (UL) limbs, proprioceptive training and stretching exercises in order to prevent complications by DM.

For the data acquisition of postural stability, it was used the F-Scan platform of pressure, model F-Mat (brand Tekscan ${ }^{\circledR}$, version 4.21, Model 3100), with a sampling frequency of $100 \mathrm{~Hz}$, calibrated according to the methodology proposed by the manufacturer.

The protocol of stabilometric signal capture used was proposed by Regolin and Carvalho ${ }^{17}$. From the use of this model, the participant was instructed to climb on the pressure platform and remain in a standing still position for 30 seconds, keeping it a comfortable position and distributing the weight evenly between each foot (Figure 1); three collections with eyes opened (EO) and three with eyes closed (EC) were performed, with an interval of one minute between each assessment. If it was necessary, the participant could make vision correction through the use of glasses.
The data relating to the fluctuations in the center of pressure (COP) within the base of support, obtained by the F-Mat sensor, were exported to the Microsoft ${ }^{\circledR}$ Office Excel program in ASCII format, went through a low-pass-fourth-order Butterworth digital filter, at phase zero, with a cutoff frequency of $05 \mathrm{~Hz}$ developed in MATLAB software. Up next, they went through a processing using a spreadsheet from Microsoft ${ }^{\circledR}$ Office Excel, in which, according to the methodology recommended by Tookuni et al. ${ }^{18}$, the first 10 seconds of each collection were excluded and the stabilometric parameters related to the total length of the trajectory (PL) of displacement of the COP, the amplitude of the COP displacements towards the anteroposterior (AP) and medial-lateral (ML) directions, and the maximum velocity (MV) achieved by the COP, were calculated.

In order to assess the risk of falls, the Berg Balance Scale $(\mathrm{BBS})^{19}$, consisting of 14 items involving specific functional tasks in different support bases, with scores ranging from 0 to 56 . Each item has an ordinal scale with five alternatives from 0 to 4 points, where 0 indicates that the individual was not able to perform the task and 4 that the subject was able to accomplish the task without difficulty; in the sum, values equal to or lower than 45 indicate risk of falling, according to the cutoff point proposed by Berg et al. ${ }^{20}$.

The Falls Efficiency Scale (FES-I) was applied to measure the fear of falling among the elderly, this scale was translated and validated for the Brazilian population by Camargos et al., who yet described that a score $\geq 23$ suggests an association with a history of sporadic fall, whereas a score $\geq 31$ entails an association with recurrent falls ${ }^{21}$.

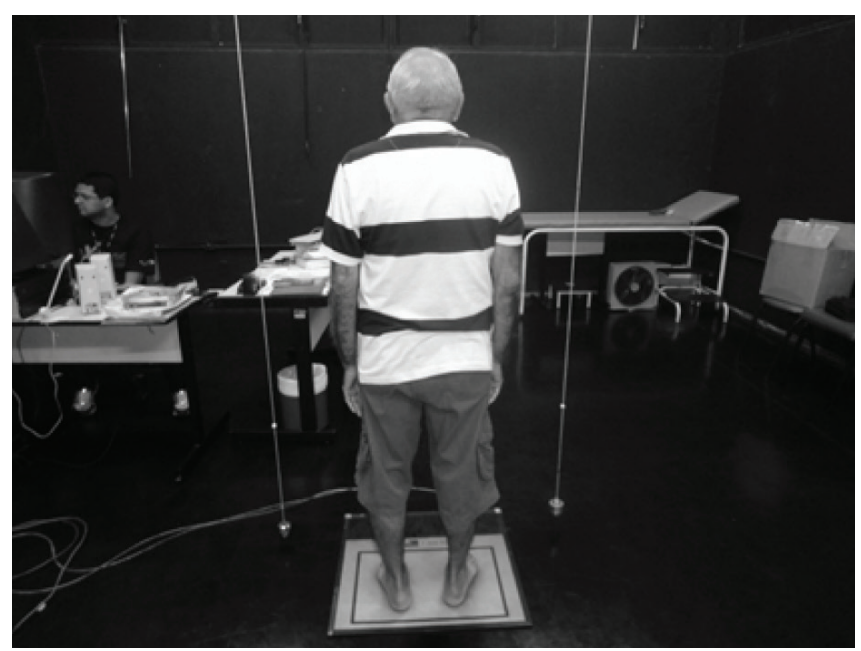

Figure 1. Acquisition of stabilometric data 


\section{Statistical analysis}

The statistical analysis was performed using the SPSS software, version 20. First, a descriptive statistical analysis (average and standard deviation) was conducted. The Kolmogorov-Smirnov test was used in order to test the normality of the data, and the analysis of the data as parametric was carried out.

The values obtained in the stabilometric variables, BBS and FES-I were compared between the groups G1 and G2 using the Student's $t$-test; the probability of type I error was set at $5 \%$ for all tests $(\mathrm{p}<0.05)$.

\section{RESULTS}

The 50 seniors with DNP who participated in the study were divided into two groups: G1, consisting of 24 elderly individuals ( 20 women) who were conducting therapeutic exercises guided by service's physical therapists for, at least, three months, and G2, of 26 elderly people (21 women) who would not practice any exercise. The participants' characteristics may be observed in Table 1 .

In Table 2, the stabilometric variables of the pressure platform comparing the groups, once the individuals with DNP who did not perform therapeutic exercises performed worse in the trajectory parameters of displacement with eyes closed (PLEC) and of mediallateral displacement with eyes closed (MLEO) are observed, with statistically significant difference ( $\mathrm{p}=0.01$ and $\mathrm{p}=0.004$, respectively).

In Table 3, the values of the BBS and the FES-I between the groups G1 and G2 are observed. No statistically significant differences between groups were observed, indicating that the group which carried out the protocol of therapeutic exercise was not effective in minimizing the risk and the fear of falling among elderly patients with DNP.

\section{DISCUSSION}

In the present study a significant difference was found between the group which performed therapeutic exercises and the one which would not perform them through the pressure platform in the PLEC and MLEO parameters.

Centomo et al. evaluated postural stability among older adults with type $2 \mathrm{DM}$ with and without DNP, also using the force platform, and no differences were observed between the groups which would corroborate with the present study; a justification given by the authors is that, even not having a diagnosis of DNP, the diabetics already have changes in postural responses which may influence in balance, and therefore there were no differences between groups ${ }^{22}$.

Corriveaux et al. found that elderly people with DNP showed significant increases of AP and ML fluctuations, when compared to the group of elderly without DNP, with both EO and EC, proving that these individuals are less stable and have increased risk of falling ${ }^{23}$. In the present study, there was no control group of patients without DM, which made it impossible to see whether such an increase of the oscillation of AP and ML would also occur in the population studied; however, there were differences between the groups with and without a history of falls regarding the PLEC and MLEC variables.

In this research, a significant difference was observed between groups in the PLEC and the MLEC

Table 1. Characterization of the sample of elderly patients with diabetic neuropathy

$\begin{array}{lcc} & \text { G1 } & \text { G2 } \\ \text { Subjects } & 24 & 26 \\ \text { Age (years)* } & 67.8 \pm 7.0 & 65.5 \pm 4.9 \\ \text { Time of DM (years)* } & 15.7 \pm 9.1 & 15.7 \pm 9.1 \\ \text { History of fall within the past six months } & 15 & 20 \\ \text { Reported fear of falling } & 13 & 17\end{array}$

DM: diabetes mellitus; G1: perform therapeutic exercises; G2: control group. *mean \pm standard deviation

Table 2. Comparison of the stabilometric values of the pressure platform

$\begin{array}{lccc} & \begin{array}{c}\text { G1 } \\ \text { Mean } \pm \text { SD }\end{array} & \begin{array}{c}\text { G2 } \\ \text { Mean } \pm S D\end{array} & \text { p-value } \\ \text { PLEO } & 185.02 \pm 62.84 & 167.87 \pm 46.64 & 0.10 \\ \text { APEO } & 0.43 \pm 0.18 & 0.43 \pm 0.17 & 0.85 \\ \text { MLEO } & 0.69 \pm 0.69 & 0.68 \pm 0.68 & 0.36 \\ \text { MVEO } & 40.11 \pm 15.43 & 38.37 \pm 15.08 & 0.57 \\ \text { PLEC } & 191.42 \pm 72.70 & 162.74 \pm 46.51 & 0.01^{*} \\ \text { APEC } & 0.42 \pm 0.16 & 0.39 \pm 0.18 & 0.91 \\ \text { MLEC } & 0.73 \pm 16.89 & 0.60 \pm 17.12 & 0.004^{*} \\ \text { MVEC } & 40.10 \pm 20.53 & 35.05 \pm 13.41 & 0.43\end{array}$

PLEO: Path length with eyes opened; APEO: anteroposterior movement with eyes opened;

MLEO: medio-lateral movement with eyes opened; MVEO: Maximum velocity with eyes opened PLEC: path length with eyes closed; APEC: anteroposterior movement with eyes closed; MLEC: medio-lateral movement with eyes closed; MVEC: maximum velocity with eyes closed; ${ }^{*} p<0.01$; G1: perform therapeutic exercises; G2: control group; SD: standard deviation

Table 3. Data of the Berg Balance Scale and the Falls Efficiency Scale between G1 and G2

$\begin{array}{lccc} & \begin{array}{c}\text { G1 } \\ \text { Mean } \pm \text { SD }\end{array} & \begin{array}{c}\text { G2 } \\ \text { Mean } \pm \text { SD }\end{array} & \text { p-value } \\ \text { BBS } & 50.25 \pm 4.13 & 46.92 \pm 7.27 & 0.16 \\ \text { FES-I } & 30.41 \pm 8.39 & 28.11 \pm 10.45 & 0.15\end{array}$

BBS: Berg Balance Scale; FES-I: Falls Efficiency Scale; G1: perform therapeutic exercises; G2: control group; SD: standard deviation 
variables, which may be justified by a better activation of the ankle strategy for the maintenance of postural stability.

In the study by Cenci et al., the diabetic elderly were evaluated by the use of the F-Scan system, the esthesiometry and the BBS, and had their balance disorders assessed by this sensor and by the BBS, i.e., the individuals assessed are outside the risk of falling, even with the decrease or absence of the protective plantar sensitivity, showing, in this case, that the physical therapy intervention, particularly through therapeutic exercises, was beneficial for maintaining and/or improving body balance, reducing then the risk of falls and increasing independence in $\mathrm{DAs}^{24}$. Such finding corroborates the present, confirming that the group who would perform therapeutic exercises obtained better values in the PLEC and the MLEC parameters on the pressure platform.

Although the force platform is the most widely used tool for postural assessment, there is no consensus on the COP variables used in the assessment of postural stability of the patients being tested, which can make it rather difficult to compare results between studies, besides the lack of researches using the force platform in this population ${ }^{25}$. In the presented study, the PLEC and the MLEC parameters showed significant differences between the groups G1 and G2, but there is no way of confirming through literature whether these parameters would have the sensitivity and specificity to indicate the risk of falling.

The improvement in physical performance can be achieved through changes in the patterns of exercise prescription considering the matters of dose and effect, in which the aspects weekly frequency, number of sets and repetitions, speed of execution and periodic resting period should be considered, allowing a better relationship between stress/recovery oriented to the increase of muscle mass and to generate effects in the prevention of falls ${ }^{26-28}$. In the presented study, despite not having been taken into account the standardization of the protocol of executed exercises, there was no difference between groups in stabilometric parameters, however, no significant differences in the values of the BBS between G1 and G2 were observed, considering the lower cutoff point as 45 points as an indicator of risk factor for falls.

Regarding the score of BBS, Bretan et al. ${ }^{11}$ proposed different cutoff points from the recommended ones by Berg et al. ${ }^{18}$, which is 45 for risk of falls; these authors compared the BBS to the $10 \mathrm{~g}$ monofilament and, through the construction of a ROC curve, suggested a new cutoff point of 48 or 49 for the $\mathrm{BBS}$, considering the DM as a risk factor for falls among the elderly. Based on this cutoff point, it was possible to notice that G1 got a score close to the new cutoff point and G2 got a score lower than the cutoff of the BBS, suggesting that DNP is a leading factor for the postural instability of this population, especially among elderly who did not perform therapeutic exercise.

Kanade et al. Observed, in their study, that the static balance is directly affected by the complications arising from the DNP and that balance training should be part of the rehabilitation program of these individuals ${ }^{29}$, confirming the difference found in the present study, in which the PLEC and the MLEC parameters were better in patients with a history of regular physical activity.

As for the fear of falling, approximately 20 to $60 \%$ of patients have experienced fear of falling without even having occurred the episode of the fall, and the frequency is higher in women, especially when they are sedentary or have a history of depression ${ }^{30,31}$, however, no associations between the fear of falling and the therapeutic exercises were observed in the present study.

This study presents the limitations of the following aspects: sample size, standardization of the intervention group and survey of neurocognitive aspects, such as education level, depression and self-sufficiency, factors which could perhaps influence the response of the volunteers in relation to the fear of falling.

\section{CONCLUSION}

Seniors with DNP who perform therapeutic exercises differ in postural stability, assessed by pressure platform with $\mathrm{EC}$ in $\mathrm{PL}$ parameters and ML stability of the stabilometric signal. There was no difference in the risk of falls and the fear of falling between the groups evaluated in this study.

\section{REFERENCES}

1. Mendes TAB, Moisés G, Neuber JS, Marilisa BAB, Chester LGC, Carandina L, et al. Diabetes mellitus: fatores associados à prevalência em idosos, medidas e práticas de controle e uso dos serviços de saúde em São Paulo, Brasil. Cad Saúde Pública. 2011;27(6):1233-43.

2. Sartorelli DS, Franco LJ. Tendências do diabetes mellitus no Brasil: o papel da transição nutricional. Cad Saúde Pública. 2003; 19(Suppl. 1)11:29-36. 
3. Wild S, Roglic G, Sicree R, King H. Global prevalence of diabetes; estimates for the year 2000 and projection for 2030. Diabetes Care. 2004:27:1047-53.

4. Sacco ICN, Sartor CD, Gomes AA, João SMA, Cronfli R. Avaliação das perdas sensório-motoras do pé e tornozelo decorrentes da neuropatia diabética. Rev Bras Fisioter. 2007;11(1):27-33.

5. Schmid H, Neumann C, Brugnara L. O diabetes melito e a desnervação dos membros inferiores: a visão do diabetólogo. J Vasc Bras. 2003;2(1):37-48.

6. Oppenheim U, Kohen-Raz R, Alex D, Kohen-Raz A, Azarya M. Postural Characteristics of Diabetic Neuropathy. Diabetes Care. 1999;22(2):328-32.

7. Panel on Prevention of Falls in Older Persons, American Geriatrics Society and British Geriatrics Society. Summary of the Updated American Geriatrics Society/British Geriatrics Society clinical practice guideline for prevention of falls in older persons. J Am Geriatr Soc. 2011;59(1):148-57.

8. Silva SLA, Vieira RA, Arantes P, Dias RC. Avaliação de fragilidade, funcionalidade e medo de cair em idosos atendidos em um serviço ambulatorial de geriatria e gerontologia. Fisioter Pesq. 2009;16(2):120-5.

9. Rezende AAB, Silva IL, Cardoso FB, Beresford H. Medo do idoso em sofrer quedas recorrentes: a marcha como fator determinante da independência funcional. Acta Fisiatr. 2010;17(3):117-21.

10. Tilling LM, Darawil K, Britton M. Falls as a complication of diabetes mellitus in older people. J Diabetes Complications. 2006;20(3):158-62.

11. Bretan O, Pinheiro RM, Corrente JE. Avaliação funcional do equilíbrio e da sensibilidade cutânea plantar de idosos moradores na comunidade. Braz J Otorhinolaryngol. 2010;76(2):219-24.

12. Gomes AA, Sartor CD, João SMA, Sacco ICN, Bernik MMS. Efeitos da intervenção fisioterapêutica nas respostas sensoriais e funcionais de diabéticos neuropatas. Fisioter Pesq. 2007;14(1):14-21.

13. LeMaster JW, Mueller MJ, Reiber GE, Mehr DR, Madsen RW, Conn VS. Effect of Weight-bearing activity on foot ulcer incidence in people with diabetic peripheral neuropathy: feet first randomized controlled trial. Phys Ther. 2008;88(11):1385-98.

14. Kruse RL, Lemaster JW, Madsen RW. Fall and balance outcomes after an intervention to promote leg strength, balance, and walking in people with diabetic peripheral neuropathy: "feet first" randomized controlled trial. Phys Ther. 2010;90(11):1568-79.

15. Morrison S, Colberg SR, Mariano M, Parson HK, Vinik Al. Balance training reduces falls risk in older individuals with type 2 diabetes. Diabetes Care. 2010;33(4):748-50.

16. Moreira R, Castro AP, Papelbaum M, Appolinário JC, Ellinger VCM, Coutinho WF, et al. Tradução para o português e avaliação da confiabilidade de uma escala para diagnóstico da polineuropatia distal diabética. Arq Bras Endocrinol Metab. 2005;49(6):944-50.

17. Regolin F, Carvalho GA. Relação entre cifose dorsal, densidade mineral óssea e controle postural em idosas. Rev Bras Fisioter. 2010;14(6):464-9.
18. Tookuni KS, Neto RB, Pereira CAM, Souza DR, Greve JMD, Ayala AD. Análise comparativa do controle postural de indivíduos com e sem lesão do ligamento cruzado anterior do joelho. Acta Ortop Bras. 2005;13(3):115-9.

19. Miyamoto ST, Lombardi Junior I, Berg KO, Ramos LR, Natour J. Brazilian version of the Berg balance scale. Braz J Med Biol Res. 2004:37(9):1411-21.

20. Berg KO, Wood-Dauphinee SL, Williams JI, Maki BE. Measuring balance in the elderly: validation of an instrument. Can J Public Health. 1992;83(Suppl. 2):S7-11.

21. Camargos FFO, Dias RC, Dias JMD, Freire MTF. Adaptação transcultural e avaliação das propriedades psicométricas da Falls Efficacy ScaleInternational em idosos brasileiros (FES-I-BRASIL). Rev Bras Fisioter. 2010;14(3):237-43.

22. Centomo H, Termoz N, Savoie S, Béliveau L, Prince F.. Postural control following a self-initiated reaching task in type 2 diabetic patients and age-matched controls. Gait Posture. 2007:25(4):509-14.

23. Corriveaux H, Prince F, Hébert R, Raîche M, Tessier D, Maheux P, et al. Evaluation of postural stability in elderly with diabetic neuropathy. Diabetes Care. 2000;23(8):1187-91.

24. Cenci DR, Silva MD, Gomes EB, Pinheiro HA. Análise do equilíbrio em pacientes diabéticos por meio do sistema F-Scan e da escala de equilíbrio de Berg. Fisioter Mov. 2013;26(1):55-61.

25. Duarte M, Freitas SMSF. Revisão sobre posturografia baseada em plataforma de força para avaliação do equilíbrio. Rev Bras Fisioter. 2010;4(3):183-92.

26. Prestes J, De Lima C, Frollini AB, Donatto FF, Conte M. Comparison of linear and reverse linear periodization effects on maximal strength and body composition. J Strength Cond Res. 2009;23(1):266-74

27. Sherrington C, Tiedemann A, Fairhall N, Close JC, Lord SR. Exercise to prevent falls in older adults: an updated meta-analysis and best practice recommendations. N S W Public Health Bull. 2011;22(3-4):78-83.

28. Zijlstra GAR, van Haastregt JC, van Rossum E, van Eijk JT, Yardley $\mathrm{L}$, Kempen GI. Interventions to reduce fear of falling in communityliving older people: a systematic review. J Am Geriatr Soc. 2007;55(4):603-15.

29. Kanade RV, Van Deursen RW, Harding KG, Price PE. Investigation of standing balance in patients with diabetic neuropathy at different stages of foot complications. Clin Biomech (Bristol, Avon). 2008;23(9):1183-91.

30. Lopes KT, Costa DF, Santos LF, Castro DP, Bastone AC. Prevalência do medo de cair em uma população de idosos da comunidade e sua correlação com mobilidade, equilíbrio dinâmico, risco e historio de quedas. Rev Bras Fisioter. 2009;13(3):223-9.

31. Mazo GZ, Liposcki DB, Ananda C, Prevê D. Condições de saúde, incidência de quedas e nível de atividade física dos idosos. Rev Bras Fisioter. 2007;11(6):437-42. 